\title{
THEATER PERFORMANCE ANALYSIS FORBIDDEN FROM SINGING IN \\ BATH ROOM BY SENO GUMIRA AJIDARMA THEATER HAD STUDY PROGRAM IN INDONESIAN LANGUAGE AND LITERATURE EDUCATION TRUNOJOYO MADURA UNIVERSITY (CARLES SANDERS PEARCE SEMIOTIC STUDY)
}

\author{
Ahmad Jami'ul Amil, S.Pd., M.Pd. \\ Indonesian Language and Literature Education Study Program, \\ University of Trunojoyo Madura \\ e-mail: ahmadamil@trunojoyo.ac.id
}

\begin{abstract}
This research is descriptive qualitative research that examines theatrical performances of scripts. It is forbidden to sing in the bathroom. The work of Seno GumiraAjiDarma is the study of semiotic carlesanderspearce. The formulation of the problem in this research is how the study of semiotics in the tetater show had once been conducted by the PBSI Study Program using the study of semiotic carles sanders Pearce. Data collection techniques using documentation techniques, note, and see. The analysis technique used is reducing data, promising data, and verifying data. From the results of the study concluded that the semiotics that appear on signs and markers in the form of symbols are the dance of the bathroom, sound, and the shadow of the bathroom. The index aspect is in the form of actor actions in the form of exoticism, anxiety, admiration, exoticism, and the imagination of the actor. The iconic aspect is shown in one of the events, namely the social environment in the form of a house, bathroom, and boarding house.
\end{abstract}

Keywords: Theater, Manuscripts, and Semiotic. 


\section{INTRODUCTION}

The development of theater in Indonesia adjusts to social and political development, historical records state that political development was very dominant during the decade of Rendra and his compatriots, while being drawn back during the political struggle period also emerged in the YB Mangunwijaya decade, Pramoedya was pulled back again until the Dutch occupation and japan. Theater is inseparable from all activities of human thought and processing which are very closely related to the sensitivity of an author. Author will come up with ideas through literary activities for the purpose of reminding, giving promises, harassing the mind, even to interruptions, interpellations, or no-confidence motions that are poured through literary works neatly packaged by the authors. Literary works are created to be enjoyed and appreciated specifically for the purpose in accordance with the work presented, the realm of appreciation has several approaches which certainly have to do with analysis in a literary work that will be scientifically distinguished. Literary appreciation is a process (activity) of transferring, enjoying, giving out. Appreciation of literary works individually and momentarily, subjectively subjective, spiritual and mindful, solemn and devout, and intensive and total in order to obtain something thereof so that they grow, and care, sensitivity, sharpness, love, and non-involvement with literary works are maintained (Djoko Saryono, 2009: 34). The approach includes an analytical approach which is to appreciate the various sources of theories that have to do with literary scientific theories so as to bring up deep analytical results sourced from the contents of literary works.

Manuscripts, directors, and actors are parts that cannot be separated from a theater performance, the position of the script and the show shows the identity of the theater as a group that will visualize the condition of the script that has been written by the naska writer. Indonesian theater groups are very numerous and all have a common goal and love for the theater world. Seno Gumira Ajidarma is a writer and short story manuscript widely known in the Indonesian theater universe. According to Hartoko (1986: 131), the semiotic of the Greek word "semeion" which means sign. The science that examines signs, sign systems and the process of interpreting a sign. A sign is something that indicates another item, which represents that other item. The sign is representative. Signs and relations with other signs, with the items symbolized, and with the person wearing the sign. One of the manuscripts that speak of a symbol in each of the following is the Forbidden Sing in the Bath Room. Theater performance is a form of imitation (mimesis) of real life which ultimately also stores various signs and symbols in it. In student theater performances PBSI Study Program is sourced from a script filled with symbols and signs, because surtadara deliberately re-reveals cases that filter around individuals individually or in a particular group caused by modernity, also rebuilds the memories of the theater audience about issues that may often surround Public.

\section{RESEARCH METHODS}

The method used in this study uses qualitative methods. Qualitative research is a type of research with detailed and in-depth research material based on phenomena and events that are directly observed by researchers (Soedarsono, 2001: 46). While the type of research used in this study is descriptive qualitative. The term descriptive it self in epistemology can mean to describe. Thus, descriptive research can be interpreted as research that describes the facts that exist (Ratna, 2013: 53). The object 
in literary works is the reality of life (Muslimin, 2011: 131). The object of this research is that the theater performances of PBSI UTM Study Program students with the title Forbidden to Sing in the Madni Room by Seno Gumira Ajidarma that were staged at a theater performance had a PBSI Study Program on June 18, 2019 with a duration of 35 minutes.

\section{DISCUSSION}

\section{A. Social and Economic Aspects}

In this performance, the social aspect can be seen from the middle social strata in a village complex that has the middle social strata as evidenced by simobol the similarity of clothes and speech as well as the language that arises by the actor. The scene of an organized social start shows the management of a village that has been arranged, namely the management of the RT to the security devices that have an important role in preaching and accurate news. This scene is a habit that is often done by the social conditions of the Menega class society in the area of the village described by the director. Economic conditions are very clearly depicted in every activity of the powerful actors in economic issues, for example in the aspect of gender injustice when the main player controls his own life akbita from the trust of his household. It was followed by another player, the men and women followed the passions by taking part in all the activities in the bathroom carried out by the main player. This shows that the problem of sexual sensitivity in the village area still has problems, one of which is added to the presence of the main players and economic problems that have not been completed in the household of the players.

\section{B. Cultural and Art Aspects}

Culture as a symbol of literary identity that is thick with life in the performance of the manuscript. The cultural symbol appears on the pos kamling sign, the clever room which is located outside the residents' house, the culture of collision, courtesy through communication between the leader and subordinates using local languages. In the aspect of art in the performance there are aspects of artistic activities namely patrolling by playing a kentongan musical instrument. Kentongan is a symbol of art in the area of the village as a sign of village preparedness in dealing with crime and other actions that can cause noise in the area of the village.

\section{Industry and Gender Aspects}

In the industrial aspect, it can be seen in the life issues surrounding the main actors, namely in the aspects of work and economic activities, especially industry. Communities work in factories, or livelihood activities involving modernity or activities that support increasingly less interaction between humans and other humans in their lives, especially in the village complex. Another aspect of the emergence of industrial boarding houses inhabited by industrial workers resulted in environmental damage due to the rapid development of settlements. The bar opening emerged as a residence for industrial workers and offices not far from the village. The main character emerged as part of the minority who were marginalized due to being accused of being the mastermind of the emergence of problems of men who felt compelled from bathroom activities, so that the mothers who became fathers' wives became furious and eventually expelled the main characters from the village. This is where the gender problem arises which fights against minorities. 


\section{Icons, Indexes, and Symbols}

\section{The Scene of a Community Gathering}

The icon in this scene is seen in the buying and selling activities between vegetable traders and residents, especially the women in the village area. The scene raises a problem when there are a number of mothers who talk about fathers who recently have a special disruption to the problem of romance. Mounin's argument is based on the thought that communication with language media depends on the capacity of two parties or more involved in the exchange, that is the capacity in using the same codes, so that 'in turn, the message sender can be the receiver as well', 'and the receiver can be the sender' (Sahid, Nur. 2013:54). The problem was added by the news that the source of the problem was based on the presence of women who frequently quizzed in the bathroom. The activity shows that the activity indicates a gathering place for mothers to express problems that will sometimes cause problems and ultimately there is no way out.

\section{The Scene of the Bath and Imagination of the Bathroom}

The bathroom and the environmental safety officer as a symbol of activity were problems surrounding the fathers in the village. The bathroom is not only a symbol of the pin, but there are activities that are the main problem including bathing, penginatain penghata, fathers, and Mr. RT. From the results of these activities are always on the aspects of the imagination of the fathers who are surrounded by exotic imagination. This shows the symbol of activity as a form of problem that is part of the problem in the theater performance. In addition to these activities, there were several activities of sighing, changing, lighting, and removing towels as a symbol of activities that invite the problem of men's imagination. This was counteracted by activities that were known to some other residents so as to cause noise and the peak of the problems at the eviction were there were the main figures so as to be very clear in the absence of problem solving or the law carried out to resolve the problems in the village.

\section{CONCLUSION}

Literary activity is identical to the appreciation of special audiences in snei theater, the performance of activities derived from manuscripts and manuscripts will illustrate social problems. The issue was raised to illustrate how the problem was resolved or even appeared inadequate in the minority aspects. manuscripts that speak of a symbol in each of the next page is a script forbidden to sing in the Madi Room. Theater performance is a form of imitation (mimesis) of real life which ultimately also stores various signs and symbols in it. In a student theater performance PBSI Study Program is sourced from the manuscript filled with symbols and signs. The icons, indexes and symbols are, community associations, imagination, interest. The appearance of icons, indices, and symbols is covered by causes from several aspects namely, social, economic, industrial, gender, cultural and artistic aspects. 


\section{REFERENCES}

Hartoko, Dick dan B. Rahmanto. 1986. Guides in the World of Literature. Jogjakarta: Kanisus.

Muslimin. (2011). Modernization in the novel Shenggu by Armijn Pane "A Study of Literary Sociology". ISSN 2088-6020 Vol. 1. No. 1

Ratna, Nyoman Kutha. 2013. Theories, Methods and Techniques of Literary Research. Yogyakarta: Student Library.

Sahid, Nur M. (2013). Theatre Performance Communicationfrom The Perspective Of Theatre Semiotics. Journal Humaniora, Vol. 25. No. 1 Februari 2013

Saryono, Djoko 2009. Introduction to Literary Appreciation. Malang: State University of Malang.

Soedarsono. R. M. 2001. Performing Arts and Fine Arts Research Methodology. Bandung: MSPI (Masyarakat Seni Pertunjukan Indonesia). 